\title{
Keefektifan pendekatan CTL dan discovery ditinjau dari prestasi, kemampuan berpikir kritis dan kecemasan matematika
}

\author{
Enggar Prasetyawan \\ Universitas Pamulang. Jalan Surya Kencana No. 1, Pamulang, Tangerang Selatan, 15417, Indonesia. \\ * Corresponding Author. E-mail: enggar.prasetyawan@uny.co.id \\ Received: 3 September 2018; Revised: 17 October 2018; Accepted: 21 December 2018
}

\begin{abstract}
Abstrak
Penelitian ini bertujuan untuk untuk mendeskripsikan keefektifan dan perbedaan keefektifan pendekatan Contextual Teaching and Learning (CTL) dan Discovery ditinjau dari prestasi belajar, kemampuan berpikir kritis, dan kecemasan matematika. Penelitian ini adalah penelitian eksperimen semu dengan desain nonequivalent groups prestest-posttest. Populasi dalam penelitian ini adalah seluruh siswa kelas X SMA Negeri 2 Ngaglik. Sampel penelitian ini adalah kelas X MIA 2 dan X MIA 4 yang diperoleh melalui pemilihan secara acak dari empat kelas yang masing-masing siswanya berjumlah 31 orang. Instrumen yang digunakan untuk mengumpulkan data adalah tes prestasi belajar berupa soal pilihan ganda yang terdiri dari 20 butir soal, tes kemampuan berpikir kritis berupa soal uraian yang terdiri dari 4 butir soal, dan angket kecemasan matematika yang terdiri dari 32 butir pernyataan. Pengujian keefektifan pendekatan CTL dan discovery dilakukan dengan uji one sample ttest. Pengujian perbedaan keefektifan antara pendekatan CTL dan Discovery dilakukan dengan uji MANOVA (Hotteling's Trace). Hasil penelitian menunjukkan bahwa (1) pendekatan CTL dan discovery efektif ditinjau dari prestasi belajar, kemampuan berpikir kritis, dan kecemasan matematika, (2) tidak ada perbedaan keefektifan pendekatan CTL dan Discovery ditinjau dari prestasi belajar, kemampuan berpikir kritis, dan kecemasan matematika.
\end{abstract}

Kata Kunci: CTL, discovery, prestasi belajar, kemampuan berpikir kritis, kecemasan matematika

\section{Effectiveness of CTL and discovery approach viewed from students' achievement, critical thinking ability, and math anxiety}

\begin{abstract}
This study aimed to describe the effectiveness and difference of effectiveness between of Contextual Teaching and Learning (CTL) and discovery approach viewed from students' learning achievement, critical thinking ability, and math anxiety. This research was quasi experiment with nonequivalent groups prestest-posttest design. The population in this study was all students of class $X$ of SMAN 2 Ngaglik. The sample of the study was the students of X MIA 2 and X MIA 4 which is determined randomly from four classes which each of that classes consist of 31 students. The instruments used to collect data were a learning achievement test consisting of 20 multiple choice questions, a critical thinking ability test consisting of 5 essays, and math anxiety questionnaires that consisted of 32 statements. To determine the effectiveness of Contextual Teaching and Learning (CTL) and Discovery approach, one sample t-test was used. To discover the difference of effectiveness between Contextual Teaching and Learning (CTL) approach and Discovery approach MANOVA (Hotteling's Trace) was used. The results show that (1) Contextual Teaching and Learning (CTL) and Discovery approach are effective viewed from student's learning achievement, critical thinking ability, and math anxiety,(2) there is no difference in effectiveness between Contextual Teaching and Learning (CTL) approach and Discovery approach viewed from student's learning achievement, critical thinking ability, and math anxiety.
\end{abstract}

Keywords: CTL, discovery, learning achievement, critical thinking, math anxiety

How to Cite: Prasetyawan, E. (2018). Keefektifan pendekatan CTL dan discovery ditinjau dari prestasi, kemampuan berpikir kritis dan kecemasan matematika. Pythagoras: Jurnal Pendidikan Matematika, 13(2), 168180. doi:https://doi.org/10.21831/pg.v13i2.21221

https://doi.org/10.21831/pg.v13i2.21221 


\section{PENDAHULUAN}

Matematika sebagai salah satu ilmu dasar mempunyai peranan penting dalam dunia pendidikan serta dalam upaya penguasaan ilmu pengetahuan dan teknologi. Oleh karena itu, penguasaan terhadap matematika merupakan suatu keharusan apalagi di era persaingan global. Seperti yang dinyatakan oleh National Council Teacher of Mathematics (NCTM), bahwa kebutuhan untuk memahami dan dapat menggunakan matematika dalam kehidupan sehari-hari dan di tempat kerja akan terus meningkat (NCTM, 2000, p.4). Dengan sendirinya setiap orang akan merasa dituntut untuk dapat menguasai matematika.

Matematika sangat penting diajarkan di sekolah untuk membekali siswa dengan berbagai kemampuan agar dapat bersaing di era globalisasi terutama dalam bidang ilmu pengetahuan dan teknologi. Matematika juga dipercaya dapat meningkatkan kemampuan dan keterampilan dalam berpikir siswa. Salah satu kemampuan berpikir yang sangat penting untuk dimiliki siswa adalah kemampuan berpikir kritis. Kemampuan berpikir kritis dalam kehidupan sehari-hari dibutuhkan seseorang untuk melakukan pilihanpilihan yang tepat dalam hidupnya. Analisis dan evaluasi pendapat yang ditemukan sangat diperhatikan dalam proses berpikir kritis. (Brink \& Budgen, 2006, p.1; Gambrill \& Gibb, 2009, p.4; Paul \& Elder, 2008, p.2).

Berpikir kritis menekankan pada pemikiran yang rasional atau masuk akal dan reflektif sehingga dapat mencapai proses pengambilan keputusan (Ennis, 1996, p.166). Sejalan dengan hal tersebut, Lau (2011, p.1) menyatakan bahwa "critical thinking is thinking clearly and rationally. It involves thinking precisely and systematically, and following the rules of logic and scientific reasoning, among other things". Dalam matematika, proses pengambilan keputusan berhubugan erat dengan aktifitas pemecahan masalah. Ketika memecahkan suatu masalah matematika, siswa perlu melakukan pertimbangan yang masuk akal dan reflektif sehingga dapat mengambil keputusan tentang solusi yang tepat dan benar yang dapat digunakan untuk menyelesaikan masalah tersebut. Sudah seharusnya siswa memiliki kemampuan berpikir kritis yang tinggi agar dapat menyelesaikan masalah dengan baik, termasuk masalah matematika.

Aspek kemampuan berpikir kritis meliputi mengidentifikasi, menganalisis, mengevaluasi, dan menarik kesimpulan (Ennis, 2011, p.2;
Kanik, 2010, p.23; Glazer, 2001, p.14). Aspek mengidentifikasi terkait dengan mengidentifikasi suatu masalah atau situasi. Aspek menganalisis terkait dengan menentukan informasi yang relevan dan tidak relevan serta menyelesaikan masalah. Aspek mengevaluasi terkait dengan menilai kesimpulan suatu pernyataan. Aspek menarik kesimpulan terkait dengan menyimpulkan suatu masalah.

Pada kenyataannya kemampuan berpikir kritis siswa di Indonesia masih tergolong rendah. Program For Internasional Student Assessment (PISA) menunjukkan hasil bahwa siswa Indonesia menempati urutan 64 dari 65 negara (OECD, 2014, p.19). PISA mengukur kompetensi siswa dalam 3 aspek utama yaitu isi (struktur) materi yang diperoleh siswa, proses siswa dalam menyajikan argumentasi dan respon siswa saat menghadapi masalah terkait kehidupan seharihari yang melibatkan model matematika dan perhitungan matematis (OECD, 2004, p.25). Tiga aspek tersebut berkaitan dengan kemampuan berpikir kritis siswa.

Hasil tersebut didukung oleh fakta yang ditemukan di SMA N 2 Ngaglik, khusunya kelas $X$ MIA. Berdasarkan observasi di kelas X MIA SMA N 2 Ngaglik diketahui bahwa kemampuan berpikir kritis siswa masih tergolong rendah. Hal ini terlihat ketika siswa diminta guru untuk menyelesaikan suatu permasalahan matematika, mereka dapat menyelesaikannya tetapi belum bisa memberikan argumen yang tepat terkait jawaban mereka. Berdasarkan fakta tersebut, dapat disimpulkan bahwa kemampuan berpikir kritis siswa dalam menyelesaikan permasalahan matematika masih perlu ditingkatkan.

Salah satu faktor penyebab lemahnya kemampuan berpikir kritis siswa adalah proses pembelajaran yang dilaksanakan. Pembelajaran matematika haruslah melibatkan siswa secara aktif serta memfasilitasi siswa untuk dapat menggunakan kemampuan berpikirnya. Seperti yang diungkapkan oleh Johnson (2002, p.184) bahwa apabila siswa diberi kesempatan untuk menggunakan pemikiran dalam tingkatan yang lebih tinggi di setiap tingkat kelas, pada akhirnya mereka akan terbiasa membedakan antara kebenaran dan kebohongan, penampilan dan kenyataan, fakta dan opini, pengetahuan dan keyakinan. Dengan demikian siswa secara alami akan dapat membangun argumen yang didasari bukti logis dan terpercaya. Hal tersebut sejalan dengan Peraturan Menteri Pendidikan dan Kebudayaan Nomor 59 tahun 2014 tentang kurikulum SMA yang juga mengharapkan dalam praktek pembel- 
ajaran guru melatih dan membimbing siswa berpikir kritis dan kreatif dalam menyelesaikan masalah (Kemendikbud, 2014, p.381).

Faktanya masih terdapat pembelajaran yang berpusat pada guru dan kurang memfasilitasi siswa untuk aktif belajar. Hasil observasi di SMA N 2 Ngaglik menunjukkan bahwa pembelajaran matematika yang diterapkan guru di sekolah belum mengoptimalkan kemampuan berpikir kritis siswa. Guru masih cenderung mendominasi pembelajaran sehingga pembelajaran menjadi kurang bermakna bagi siswa. Jika proses pembelajaran matematika yang seperti itu terus menerus dilakukan, besar kemungkinan kemampuan berpikir kritis siswa tidak akan berkembang bahkan cenderung menurun. Tentu hal tersebut dapat berdampak pada rendahnya prestasi belajar siswa karena terdapat hubungan positif antara kemampuan berpikir kritis dan prestasi belajar siswa (Jacob, 2012; Kamaei \& Weisani, 2013).

Faktor lain yang diduga dapat menyebabkan rendahnya prestasi belajar terletak pada aspek psikologi siswa yaitu adanya kecemasan matematika. Kecemasan matematika umumnya didefinisikan sebagai perasaan tegang, ketakutan, atau takut yang mengganggu kinerja matematika (Ashcraft, 2002, p.181; Blazer Christie, 2011, p.1). Kecemasan mengacu pada perasaan umum dari kegelisahan dan kesusahan yang tidak tentu, menyebar, tidak pasti, dan sering tanpa bentuk yang terbentuk dari ancaman atau bahaya (Zeidner \& Matthews, 2011, p.5). Sejalan dengan hal tersebut, Mayer (2008, p.4) menjelaskan bahwa kecemasan merupakan reaksi pikiran tubuh yang terjadi secara instan, dan dampaknya sangat terasa secara fisiologis, perilaku, dan psikologis semua berlangsung pada saat yang sama.

Ada banyak gejala kecemasan mulai dari yang ringan seperti grogi ketika menjawab pertanyaan di kelas, hingga yang parah seperti pikiran kosong atau serangan kepanikan ketika diminta mengerjakan di papan tulis untuk menyelesaikan soal. Tidak jarang hal ini membuat siswa gagal menyelesaikan soal yang diberikan. Kegagalan semacam inilah yang dapat menjadi bumerang dan membuat anak apatis atau takut menghadapi masalah yang berujung pada timbulnya kecemasan matematika (Napitupulu, 2008). Adanya kecemasan matematika akan mengakibatkan prestasi belajar matematika siswa yang rendah karena terdapat korelasi negatif antara kecemasan matematika dengan prestasi belajar siswa (Sherman \& Wither, 2003; Zakaria \& Nordin, 2008)
Berdasarkan hasil wawancara dengan guru matematika di SMA N 2 Ngaglik, teridentifikasi bahwa kecemasan matematika siswa masih tergolong tinggi. Ketika siswa diberikan suatu soal dan diminta untuk mengerjakan ke depan kelas, sebagian besar siswa terlihat kesulitan mengerjakan soal tersebut, siswa juga terlihat gelisah dan gugup dalam mengerjakannya. Kecemasan matematika ini berdampak langsung pada prestasi belajar siswa-siswa tersebut.

Berdasarkan daya serap ujian nasional pada tahun pelajaran 2013/2014 dan 2014/2015 diketahui bahwa prestasi belajar di SMA N 2 Ngaglik masih perlu ditingkatkan khususnya pada materi geometri. Pada tahun pelajaran 2013/2014 tercatat daya serap ujian nasional untuk materi geometri adalah 49,23 dan pada tahun pelajaran 2014/2015 adalah 31,71. Terlihat bahwa daya serap ujian nasional pada materi geometri mengalami penurunan.

Salah satu hal yang dapat memicu munculnya kecemasan matematika diantaranya pendekatan pembelajaran yang tidak tepat dan tidak menyenangkan bagi siswa. Menurut Wu (Thijsse, 2002, p.8) penyebab dari kecemasan matematika bukan pada kemampuannya tetapi pada proses pembelajarannya. Hal senada juga diungkapkan oleh Arem (2010, p.19) yang menyatakan bahwa salah satu penyebab kecemasan matematika adalah guru tidak menerapkan pembelajaran yang efektif. Salah satu wilayah yang berkontribusi adanya kecemasan matematika siswa yaitu strategi pembelajaran (Sousa, 2008, p.174). Oleh karena itu, guru diharapkan mampu memahami dan menerapkan berbagai pendekatan pembelajaran yang sesuai dengan kekhasan materi dan karakteristik siswa sehingga pembelajaran matematika menjadi aktif dan menyenangkan.

Berdasarkan hal tersebut, diperlukan suatu perubahan mendasar terutama terkait pendekatan pembelajaran yang digunakan, yaitu dari pendekatan pembelajaran yang berorientasi pada guru menjadi pendekatan pembelajaran yang berorientasi pada siswa. Salah satu pendekatan pembelajaran yang berorientasi pada siswa diantaranya pendekatan Contextual Teaching and Learning (CTL) dan pendekatan discovery. Kedua pendekatan pembelajaran tersebut sejalan dengan kurikulum 2013.

Pendekatan Contextual Teaching and Learning (CTL) merupakan suatu sistem pengajaran yang cocok dengan otak yang menghasilkan makna dengan menghubungkan muatan akademis dengan konteks dari kehidupan seharihari siswa (Johnson, 2002, p.58). Konsep belajar 
yang mengaitkan antara materi yang diajarkan dengan situasi dunia nyata siswa mampu mendorong siswa membuat hubungan antara pengetahuan yang dimilikinya dengan penerapannya dalam kehidupan sehari-hari serta membantu menemukan makna apa yang mereka pelajari. Pembelajaran dengan CTL tidak memposisikan siswa sebagai objek belajar akan tetapi sebagai subjek belajar (Rahmawati \& Harta, 2004, p.115). CTL diidentifikasi sebagai strategi yang menjanjikan yang secara aktif melibatkan siswa dan meningkatkan pembelajaran dan pengembangan keterampilan (Baker, Hope, \& Karandjeff, 2009, p.6). Salah satu unsur penting yang diperhatikan dalam pembelajaran kontekstual adalah menekankan pada pentingnya siswa untuk berpikir kritis dan kreatif dalam mengumpulkan data, memahami suatu isu, atau memecahkan suatu masalah (University of Washington dalam Masnur Muslich, 2008, p.48). Diharapkan pembelajaran menggunakan CTL dapat meningkatkan prestasi belajar siswa. Pembelajaran dengan pendekatan CTL menggunakan strategi pembelajaran yaitu relating (menghubung-kan), experiencing (mencoba, mengeksplorasi), applying (menerapkan), cooperting, dan transferring (mentransfer) (Crawford, 2001, p.216).

Selain pendekatan CTL, terdapat pendekatan discovery yang menuntut siswa untuk mampu menemukan suatu konsep dalam belajar. Pendekatan ini menempatkan siswa untuk aktif belajar mandiri dan mengembangkan kekreatifan dalam memecahkan masalah. Pembelajaran discovery meliputi model pembelajaran dan strategi yang memfokuskan pada keaktifan, dan memberikan kesempatan belajar bagi siswa secara mandiri. (Dewey \& Piaget dalam Castronova, 2002, p.2).

Tiga atribut utama dalam pembelajaran ini yaitu (1) melalui kegiatan eksplorasi dan memecahkan masalah siswa mencipta, mengintegrasi, dan menggeneralisasi pengetahuan; (2) kegiatan berbasis aktivitas dengan siswa menentukan urutan dan frekuensi pembelajaran; (3) aktivitas bertujuan mendorong integrasi dari pengetahuan baru ke dasar pengetahuan yang telah dimiliki siswa. (Bicknell-Holmes \& Hoffman dalam Castronova, 2002, p.2). Siswa diberikan kesempatan untuk menemukan konsep sendiri dan guru hanya berperan sebagai pembimbing dan memberikan instruksi. Jika siswa menjadi lebih aktif dan memahami konsep dalam proses pembelajaran, maka hal ini dapat mewujudkan prestasi belajar siswa menjadi lebih baik. Selain itu, pendekatan discovery dapat membangkitkan keingintahuan siswa, dengan memotivasi mereka terus bekerja dan bereksplorasi hingga mereka menemukan jawaban. Siswa juga belajar secara mandiri memecahkan masalah dan melatih keterampilan berpikir kritis, karena mereka harus menganalisis dan mengolah informasi (Slavin, 2006, p.248).

Tahapan kegiatan dalam pembelajaran discovery diantaranya adalah siswa mengidentifikasi, mengumpulkan informasi, menganalisis data, dan akhirnya sampai kepada suatu kesimpulan (Saab et al, 2005, p.604; Westwood, 2008, p.29; Cruickshank, Jenkins, \& Metcalf, 2012, p.270). Adapun langkah-langkah pembelajaran dengan pendekatan discovery yang telah disintesis dalam kurikulum 2013 yang akan digunakan dalam penelitian ini adalah mengamati, menanya, mengidentifikasi masalah, mengumpulkan informasi, menganalisis, menarik kesimpulan, dan mengkomunikasikan.

Terkait dengan pemaparan yang telah dilakukan, penelitian ini bertujuan untuk mendeskripsikan keefektifan dan perbedaan keefektifan pembelajaran matematika menggunakan pendekatan Contextual Teaching and Learning (CTL) dan pendekatan discovery ditinjau dari prestasi belajar, kemampuan berpikir kritis dan kecemasan matematika siswa.

\section{METODE}

Jenis penelitian ini adalah eksperimen semu (quasi experiment) dengan desain nonequivalent groups pretest-posttest design. Penelitian dilakukan di SMA Negeri 2 Ngaglik, Sleman, Yogyakarta tahun pelajaran 2015/2016 pada bulan Maret sampai Mei 2016.

Populasi pada penelitian ini yaitu seluruh siswa kelas X SMA Negeri 2 Ngaglik khususnya kelas MIA yang terdiri dari 4 kelas. Dipilih dua kelas secara acak untuk menjadi sampel penelitian. Selanjutnya, dilakukan pengacakan dua kelas yang terpilih terkait pemberian perlakuan. Kelas $\mathrm{X}$ MIA 4 mendapatkan perlakuan dengan pendekatan CTL dan kelas X MIA 2 menggunakan pendekatan discovery. Jumlah siswa masingmasing kelas adalah 31 orang.

Pengumpulan data penelitian dilakukan dengan memberikan instrumen pretest sebelum perlakuan, yang terdiri dari seperangkat tes prestasi belajar, tes kemampuan berpikir kritis, dan angket kecemasan matematika siswa. Prestasi belajar dan kemampuan berpikir kritis yang diukur pada penelitian ini dibatasi pada materi geometri. Pretest dilakukan untuk melihat 
Pythagoras, 13 (2), 2018 - 172

Enggar Prasetyawan

kemampuan awal siswa. Selanjutnya, diberikan tindakan penelitian pada masing-masing kelas perlakuan menggunakan pendekatan pembelajaran CTL dan discovery. Terakhir, diberikan posttest selurh kegiatan pembelajaran selesai. Posttest berupa seperangkat tes prestasi belajar, tes kemampuan berpikir kritis, dan angket kecemasan matematika siswa.

Instrumen yang digunakan untuk mengumpulkan data adalah tes prestasi belajar yang terdiri dari 20 butir soal pilihan ganda, tes kemampuan berpikir kritis berupa 4 butir soal uraian, dan angket kecemasan matematika yang terdiri dari 32 butir pernyataan dengan 5 skala.

Sebelum dgunakan, instrumen penelitian divalidasi. Validitas instrumen berupa validitas isi dengan meminta saran, masukan, serta pertimbangan dari dua dosen ahli (expert judgment) di bidang materi dan evaluasi serta validitas konstruk pada angket. Setelah divalidasi, instrumen di ujicobakan di kelas XI MIA SMA Negeri 2 Ngaglik, Sleman, Yogyakarta. Hasil uji coba instrumen digunakan untuk mengestimasi reliabilitas intrumen. Dalam penentuan koefisien reliabilitas digunakan software SPSS 17.0 for windows atau rumus Alpha Cronbach (Reynolds, Livingston, \& Willson, 2010, p.103) yaitu sebagai berikut:

$$
r_{x x^{\prime}}=\frac{k}{k-1}\left[1-\frac{\sum S D_{i}^{2}}{S D^{2}}\right]
$$

Keterangan:

$$
\begin{array}{ll}
r_{x x^{\prime}} & \text { : Koefisien Alpha Cronbach } \\
k & \text { : Banyaknya item tes } \\
S D_{i}^{2} & \text { : Varian skor siswa pada item tertentu } \\
S D^{2} & \text { : Varians skor total }
\end{array}
$$

Setelah diperoleh koefisien realibilitas instrumen, dilakukan penghitungan Standar Error Measurement (SEM) pada masing-masing instrumen dengan menerapkan rumus berikut (Nitko \& Brookhart, 2011, p.76).

$$
S E M=S D_{x} \sqrt{1-r_{x x^{\prime}}}
$$

Keterangan:

\section{SEM : Standar Erorr of Measurement \\ $S D_{x} \quad:$ Standard deviation \\ $r_{x x^{\prime}} \quad$ : Koefisien reliabilitas}

\begin{tabular}{|c|c|c|c|c|c|c|}
\hline \multirow[t]{2}{*}{ Instrumen } & \multicolumn{2}{|c|}{ Koef. } & \multicolumn{2}{|c|}{$\begin{array}{l}\text { Standar } \\
\text { Deviasi }\end{array}$} & \multicolumn{2}{|c|}{ SEM } \\
\hline & Pre & Post & Pre & Post & Pre & Post \\
\hline $\begin{array}{c}\text { Prestasi } \\
\text { belajar }\end{array}$ & 0,693 & 0,731 & 3,028 & 3,042 & 1,678 & 1,578 \\
\hline $\begin{array}{c}\text { Kemampuan } \\
\text { berpikir } \\
\text { kritis }\end{array}$ & 0,677 & 0,654 & 1,650 & 1,463 & 0,938 & 0,861 \\
\hline $\begin{array}{l}\text { Kecemasan } \\
\text { matematika }\end{array}$ & 0,9 & 06 & 15, & 698 & & 813 \\
\hline
\end{tabular}

Adapun hasil analisis reliabilitas instrumen penelitian dan nilai SEM untuk masingmasing variabel terikat disajikan pada Tabel 1.
Tabel 1. Hasil Estimasi Koefisien Reliabilitas dan Nilai SEM

Berdasarkan Tabel 1, terlihat bahwa keseluruhan instrumen yang digunakan dalam penelitian memiliki koefisien reliabilitas di atas 0,65. Dengan demikian, dapat disimpulkan bahwa seluruh instrumen tes dalam penelitian ini reliabel.

\section{Teknik Analisis Data}

Analisis deskriptif digunakan untuk mendeskripsikan data yang diperoleh melalui hasil pretest dan posttest prestasi belajar, kemampuan berpikir kritis, dan kecemasan matematika. Deskripsi dilakukan dengan mencari nilai ratarata, nilai maksimal, nilai minimal, standar deviasi dan ketuntasan dari data yang diperoleh. Perhitungan statistik deskriptif dilakukan menggunakan bantuan SPSS 17.0 for windows.

Selain analisis deskriptif, juga dilakukan analisis inferensial. Sebelum melakukan analisis, dilakukan uji asumsi terhadap kedua kelompok, baik sebelum maupun setelah perlakuan. Uji normalitas multivariat dilakukan menggunakan jarak Mahalanobis $\left(d_{i}^{2}\right)$, dengan kriteria keputusan yang digunakan yaitu asumsi normalitas multivariat terpenuhi jika sekitar $50 \%$ data mempunyai nilai $d_{i}^{2}<\chi_{(p ; 0,5)}^{2}$. Uji normalitas univariat dilakukan menggunakan uji KolmogorovSmirnov. Taraf signifikansi yang digunakan adalah 0,05 dengan kriteria keputusan yaitu asumsi normalitas terpenuhi jika nilai signifikansinya lebih dari 0,05.

Selanjutnya, untuk mengetahui homogenitas matriks varian kovarian dilakukan uji Box's $M$. Keputusan uji dan kesimpulan terhadap uji hipotesis dilakukan pada taraf signifikansi 0,05. Adapun kriteria keputusan yang digunakan adalah data dikatakan memenuhi uji asumsi homogenitas matriks varian kovarian jika nilai signifikansinya lebih dari 0,05. 
Uji Kesamaan Vektor Rerata Dua Kelompok

Dilakukan uji MANOVA pada data sebelum perlakuan untuk melihat apakah terdapat perbedaan kemampuan awal antara kedua kelas dengan menggunakan rumus sebagai berkut.

$F=\frac{n_{1}+n_{2}-p-1}{\left(n_{1}+n_{2}-2\right) p} T^{2}$ dengan

$T^{2}=\frac{n_{1} n_{2}}{n_{1}+n_{2}}\left(\bar{y}_{1}-\bar{y}_{2}\right)^{\prime} S^{-1}\left(\bar{y}_{1}-\bar{y}_{2}\right)$

(Stevens, 2009, p.148)

Dimana:

$T^{2}: T^{2}$ Hotteling's

$n_{1}$ : banyaknya subjek pada kelompok pertama

$n_{2}$ : banyaknya subjek pada kelompok kedua

$\left(\overline{\mathrm{y}}_{1}-\overline{\mathrm{y}}_{2}\right)$ : mean vektor

$\mathrm{S}^{-1}$ : invers matrik kovarians

p: banyaknya variabel dependen

Kriteria keputusannya adalah $H_{0}$ ditolak jika $F_{\text {hitung }}>F_{0,05 ; v_{1} ; v_{2}}$ dimana derajat bebasnya adalah $v_{1}=p$ dan $v_{2}=n_{1}+n_{2}-p-1$. Jika menggunakan software SPSS 17.0 for windows kriteria keputusannya yaitu $H_{0}$ ditolak jika $p$-value $<0,05$ dan $H_{0}$ diterima jika $p-$ value $>0,05$.

Uji Keefektifan Pendekatan CTL dan Discovery

Keefektifan pendekatan pembelajaran ditentukan berdasarkan indeks keefektifan pada setiap aspek yang diukur. Pendekatan CTL dan Discovery dikatakan efektif jika pada prestasi belajar siswa, skor rata-rata siswa mencapai lebih dari atau sama dengan 75 ; jika pada kemampuan berpikir kritis siswa, skor rata-rata mencapai lebih dari atau sama dengan 70; dan jika pada kecemasan matematika, skor rata-rata mencapai kurang dari atau sama dengan 85,33 dengan kriteria rendah.

Uji hipotesis yang digunakan adalah uji one sample t-test dengan rumus sebagai berikut.

$t=\frac{\bar{x}-\mu_{0}}{\frac{S}{\sqrt{n}}}$

(Tatsuoka, 1971, p.77)

Keterangan:

$\bar{x}$ : rata-rata

$\mu_{0}$ : nilai yang dihipotesiskan

$S$ : standar deviasi sampel

$n$ : ukuran sampel

Kriteria keputusan penolakan $H_{0}$ adalah jika $t_{\text {hitung }}>t_{\text {tabel }}$ dengan taraf signifikansi $\alpha=0,05$. Untuk pengujian menggunakan bantu- an SPSS 17.0 for windows, kriteria penolakan $H_{0}$ adalah jika $\frac{p \text {-value }}{2}<0,05$ dan $H_{0}$ diterima jika $\frac{p-\text { value }}{2}>0,05$.

Uji Perbedaan Keefektifan Pendekatan Pembelajaran

Analisis ini dilakukan untuk melihat ada tidaknya perbedaan keefektifan pendekatan CTL dan Discovery ditinjau dari prestasi belajar, kemampuan berpikir kritis, dan kecemasan matematika siswa. Secara statistik, perhitungan uji perbedaan keefektifan pembelajaran serupa dengan uji kesamaan vektor rerata dua kelompok (kondisi awal siswa) yang telah dilakukan sebelumnya. Perbedaannya hanya terletak pada data yang dianalisis. Untuk menentukan kondisi awal siswa, yang digunakan adalah data sebelum diberikan perlakuan (pretest), sedangkan pada analisis ini digunakan data setelah diberikan perlakuan (posttest).

Jika hasil uji multivariat terdapat perbedaan keefektifan antara kedua pendekatan pembelajaran, maka dilakukan uji lanjut (post hoc) untuk melihat pendekatan pembelajaran mana yang lebih efektif antara kelompok eksperimen 1 dengan kelompok eksperimen 2 pada masing-masing variabel terikat. Prosedur uji lanjut yang digunakan adalah Benferonni. Pengujian hipotesis dilakukan menggunakan bantuan program SPSS 17.0 for windows. Jika hasil uji multivariat menunjukkan tidak terdapat perbedaan keefektifan antara kedua pendekatan pembelajaran maka uji lanjut tidak perlu dilakukan..

\section{HASIL DAN PEMBAHASAN}

\section{Deskripsi Data}

Data yang dideskripsikan adalah data hasil tes prestasi belajar, tes berpikir kreatif, angket sikap dan minat belajar matematika siswa yang diperoleh dari kedua kelas eksperimen baik sebelum maupun sesudah perlakuan.

\section{Prestasi Belajar}

Secara ringkas hasil prestasi belajar matematika pada kedua kelas eksperimen tersaji pada Tabel 2. Pada Tabel 2 terlihat bahwa pada pendekatan CTL terjadi peningkatan skor ratarata sebesar 45,78 dan pada pendekatan discovery terjadi peningkatan skor rata-rata sebesar 47,03. Selain itu, Tabel 2 memberikan informasi bahwa skor rata-rata prestasi belajar siswa sesudah menerapkan pendekatan CTL dan discovery telah memenuhi standar KKM yang ditetapkan yaitu 75 . 
Tabel 2. Hasil Prestasi Belajar Matematika

\begin{tabular}{lcccc}
\hline \multirow{2}{*}{\multicolumn{1}{c}{ Deskripsi }} & \multicolumn{2}{c}{$\begin{array}{c}\text { Kelompok } \\
\text { (CTL) }\end{array}$} & \multicolumn{2}{c}{$\begin{array}{c}\text { Kelompok } \\
\text { (Discovery) }\end{array}$} \\
\cline { 2 - 5 } & Pre & Post & Pre & Post \\
\hline Rata-rata & 33,75 & 79,53 & 30,63 & 77,66 \\
Standar Deviasi & 8,98 & 11,46 & 8,21 & 8,71 \\
Nilai maks. ideal & 100 & 100 & 100 & 100 \\
Nilai min. deal & 0 & 0 & 0 & 0 \\
Nilai maks. & 50 & 100 & 45 & 95 \\
Nilai min. & 10 & 60 & 10 & 55 \\
Ketuntasan (\%) & 0 & 78,12 & 0 & 78,12 \\
\hline
\end{tabular}

Berdasarkan hasil analisis, dapat disimpulkan bahwa pendekatan CTL efektif ditinjau dari prestasi belajar matematika siswa. Pendekatan CTL menekankan pada keterkaitan materi pembelajaran dengan dunia kehidupan siswa secara nyata, sehingga siswa mampu menghubungkan dan menerapkan kompetensi hasil belajar dalam kehidupan sehari-hari. Melalui proses penerapan kompetensi dalam kehidupan sehari-hari, siswa akan merasakan pentingnya belajar dan mereka memperoleh makna yang mendalam terhadap apa yang dipelajarinya. Pendekatan CTL juga dapat mengkondisikan siswa untuk terus menerus mengkonstruksi pengetahuannya, setiap berhadapan dengan persoalan baru siswa akan mengkonstruksi kembali apa yang sudah dimilikinya.

Pendekatan CTL sangat erat kaitannya dengan bekerja sama yang merupakan salah satu karakteristik dalam CTL, dimana siswa dikondisikan dalam kelompok belajar untuk berbagi, berkomunikasi, saling mengoreksi, berinteraksi dengan siswa lain untuk saling membantu sama lain demi mencapai suatu tujuan belajar bersama. Disini lah salah satu peran penting pendekatan CTL dalam meningkatkan prestasi belajar siswa. Penelitian Johnson \& Johnson (Crawford, 2001, p.13) menyatakan bahwa ketika guru menggunakan strategi bekerjasama, prestasi siswa meningkat secara signifikan. Demikian pula penelitian yang telah dilakukan oleh Septiana (2015) menunjukkan bahwa pendekatan CTL efektif ditinjau dari prestasi belajar matematika. Dengan demikian, dapat disimpukan bahwa pada penelitian ini pendekatan CTL efektif ditinjau dari prestasi belajar matematika siswa.

Hasil penelitian juga menunjukkan bahwa pendekatan discovery efektif ditinjau dari prestasi belajar. Pendekatan discovery menekankan keaktifan siswa untuk menemukan sendiri konsep-konsep atau prinsip-psrinsip matematika yang benar-benar diperlukan. Seperti yang dikemukakan Dewey \& Piaget (Castronova, 2002, p.2) yang menyatakan bahwa pembelajaran discovery meliputi model pembelajaran dan strategi yang memfokuskan pada keaktifan, dan memberikan kesempatan belajar bagi siswa secara mandiri. Sejalan dengan hal tersebut, Schunk (2012, p.266) menyatakan bahwa pada pendekatan pembelajaran ini, guru mengatur kegiatan dimana siswa mencari, memanipulasi, mengeksplorasi, dan menyelidiki.

Berdasarkan hal tersebut, dapat dikatakan bahwa keterlibatan siswa secara aktif untuk menemukan sendiri konsep ataupun prinsip matematikanya membuat siswa lebih memahami apa yang mereka pelajari sehingga berpengaruh positif terhadap prestasi belajarnya. Pada penelitian yang telah dilakukan oleh Siregar (2015), ditemukan bahwa terdapat pengaruh pembelajaran segiempat dan segitiga dengan pendekatan discovery yang menekankan aspek analogi terhadap prestasi belajar dan kemampuan penalaran siswa SMP Negeri 9 Yogyakarta. Demikian pula penelitian yang telah dilakukan oleh Apriza (2015) menyimpulkan bahwa pendekatan discovery setting TPS efektif ditinjau dari kemampuan berpikir kritis dan prestasi belajar siswa. Dengan demikian dapat disimpulkan bahwa pendekatan discovery efektif ditinjau dari prestasi belajar matematika siswa.

\section{Kemampuan Berpikir Kritis}

Secara ringkas hasil kemampuan berpikir kritis pada kedua kelas eksperimen tersaji pada Tabel 3.

Tabel 3. Hasil Kemampuan Berpikir Kritis

\begin{tabular}{lcccc}
\hline \multirow{2}{*}{\multicolumn{1}{c}{ Deskripsi }} & \multicolumn{2}{c}{$\begin{array}{c}\text { Kelompok } \\
\text { (CTL) }\end{array}$} & \multicolumn{2}{c}{$\begin{array}{c}\text { Kelompok } \\
\text { (Discovery) }\end{array}$} \\
\cline { 2 - 5 } & Pre & Post & Pre & Post \\
\cline { 2 - 5 } Rata-rata & 28,13 & 73,63 & 29,88 & 73,05 \\
Standar Deviasi & 8,84 & 11,42 & 6,30 & 9,58 \\
Nilai maks. ideal & 100 & 100 & 100 & 100 \\
Nilai min. ideal & 0 & 0 & 0 & 0 \\
Nilai maks. & 50 & 93,75 & 37,5 & 87,5 \\
Nilai min. & 12,50 & 56,25 & 18,75 & 50 \\
\hline
\end{tabular}

Berdasarkan Tabel 3, pada pendekatan CTL terjadi peningkatan skor rata-rata sebesar 45,5 dan pada pendekatan discovery terjadi peningkatan skor rata-rata sebesar 43,17 . Selain itu, hasil pada Tabel 3 memberi informasi bahwa skor rata-rata kemampuan berpikir kritis siswa sesudah menerapkan pendekatan CTL dan discovery telah memenuhi KKM yang ditetapkan yaitu 70 .

Berdasarkan hasil analisis, dapat disimpulkan bahwa pendekatan CTL efektif ditinjau dari kemampuan berpikir kritis siswa. Salah satu 
strategi dalam pendekatan CTL yaitu Experiencing, yaitu pembelajaran yang didasarkan pada pengalaman dan pengetahuan yang dimiliki siswa yang kemudian dibawa ke dalam kelas. Pembelajaran dilakukan dalam konteks eksplorasi, penemuan, dan penciptaan. Hal ini berarti bahwa pengetahuan yang diperoleh siswa melalui pembelajaran mengedepankan proses berpikir kritis lewat siklus inquiry. Selain itu, salah satu komponen dalam CTL yaitu berpikir kritis dan kreatif, menyebabkan CTL dipercaya dapat meningkatkan kemampuan berpikir kritis siswa.

Sejalan dengan hal tersebut, Medrich, Calderon, \& Hoachlander (Smith, 2010, p.24) juga mengemukakan bahwa pembelajaran dengan pendekatan CTL dapat membangun kemampuan berpikir kritis dan kemampuan pemecahan masalah siswa. Penelitian yang telah dilakukan oleh Syahbana (2012, p.53) menunjukkan bahwa terdapat perbedaan signifikan dalam peningkatan kemampuan berpikir kritis matematis siswa antara yang pembelajarannya menggunakan pendekatan CTL dan menggunakan pendekatan konvensional. Dengan kata lain, pendekatan CTL dapat meningkatkan kemampuan berpikir kritis. Dapat disimpulkan bahwa pada penelitian ini pendekatan CTL efektif ditinjau dari kemampuan berpikir kritis.

Hasil penelitian ini juga menunjukkan bahwa pendekatan discovery efektif jika ditinjau dari kemampuan berpikir kritis siswa. Pada pembelajaran dengan pendekatan discovery, siswa didorong untuk belajar aktif dengan konsepkonsep dan prinsip-prinsip, dan guru mendorong siswa untuk memperoleh pengalaman dan melakukan percobaan yang memungkinkan mereka menemukan sendiri prinsip-prinsip matematikanya. Tahapan-tahapan pembelajaran dengan pendekatan discovery diantaranya mengidentifikasi masalah, mengumpulkan informasi, menganalisis, dan menyimpulkan merupakan tahapan yang menuntut siswa untuk berpikir, salah satunya berpikir secara kritis. Seperti yang dinyatakan oleh Cruickshank, Jenkins, \& Metcalf (2012, p.271) tujuan dari pembelajaran dengan metode penemuan diantaranya untuk memfasilitasi peserta didik untuk berpikir sendiri, serta untuk melatih pola berpikir tingkat tinggi.

Salah satu dari beberapa karakteristik dalam pembelajaran discovery juga menyebutkan bahwa guru memberi kesempatan eksplorasi dan berpikir mandiri dan siswa beroperasi pada tingkat kognitif tinggi yang meliputi aktivitas analisis, sintesis, evaluasi (Cruickshank, Jenkins, \& Metcalf, 2012, p.271). Terlihat jelas dari beberapa teori yang mendukung bahwa dalam pembelajaran dengan pendekatan discovery menuntut siswa untuk berpikir secara bebas, terutama berpikir kritis. Selain itu, penelitian yang telah dilakukan oleh Apriza (2015) memperoleh hasil bahwa pendekatan discovery setting TPS efektif ditinjau dari kemampuan berpikir kritis.

\section{Kecemasan Matematika}

Secara ringkas hasil angket kecemasan matematika pada kedua kelas eksperimen tersaji pada Tabel 4.

Tabel 4. Hasil Angket Kecemasan Matematika

\begin{tabular}{lcccc}
\hline \multirow{2}{*}{\multicolumn{1}{c}{ Deskripsi }} & \multicolumn{2}{c}{$\begin{array}{c}\text { Kelompok } \\
\text { (CTL) }\end{array}$} & \multicolumn{2}{c}{$\begin{array}{c}\text { Kelompok } \\
\text { (Discovery) }\end{array}$} \\
\cline { 2 - 5 } & Pre & Post & Pre & Post \\
\hline Rata-rata & 110,94 & 82,03 & 111,53 & 81,69 \\
Standar Deviasi & 8,57 & 10,70 & 10,72 & 10,08 \\
Nilai maks. ideal & 160 & 160 & 160 & 160 \\
Nilai min. deal & 32 & 32 & 32 & 32 \\
Nilai maks. & 130 & 106 & 127 & 101 \\
Nilai min. & 97 & 65 & 83 & 67 \\
\hline
\end{tabular}

Berdasarkan Tabel 4, pada pendekatan CTL terjadi penurunan skor rata-rata dari kategori tinggi menjadi kategori rendah dan pada pendekatan discovery terjadi penurunan skor rata-rata dari kategori tinggi menjadi kategori rendah juga. Tabel 4 juga memberi informasi bahwa skor rata-rata kecemasan matematika siswa sesudah menerapkan pendekatan CTL dan discovery telah memenuhi kriteria, yaitu berada pada kategori rendah $(\leq 85,33)$.

Hasil analisis menunjukkan bahwa pendekatan CTL efektif ditinjau dari kecemasan matematika. Pendekatan CTL menekankan pada keterkaitan materi pembelajaran dengan kehidupan siswa sehari-hari. Dengan mengaitkan materi pembelajaran pada kehidupan sehari-hari, siswa merasa lebih mudah memahami materi matematika. Kegiatan experiencing pada pendekatan CTL juga memfasilitasi siswa dalam memahami konsep matematika melalui proses eksplorasi dan penemuan. Kegiatan tersebut dilaksanakan dalam situasi menyenangkan (learning as an enjoy activity) dimana siswa melakukannya dengan diskusi kelompok untuk menemukan konsep matematika dan juga dalam menyelesaikan masalah.

Dalam proses eksplorasi atau dalam menemukan konsep pembelajaran, siswa telah mengenali kesulitan-kesulitan yang mereka alami dalam menemukan konsep dan kemudian mencari kebenaran konsep yang didapat baik dari 
teman, guru, maupun sumber referensi yang dimiliki. Dengan demikian, siswa tidak menyimpan kesulitan yang dialaminya terlalu lama. Perasaan cemas atau takut akibat kesulitan memahami konsep atau mengerjakan soal yang mungkin dimiliki siswa dapat segera teratasi. Kegiatan-kegiatan tersebut sebenarnya merupakan kegiatan yang berkaitan dengan proses siswa mengurai kecemasannya terhadap matematika. Dengan demikian dapat dikatakan bahwa pada pendekatan CTL dapat mengurangi tingkat kecemasan siswa terhadap matematika.

Hasil penelitian juga menunjukkan bahwa pendekatan discovery efektif ditinjau dari kecemasan matematika. Penyebab kecemasan matematika menurut Smith (2013, p.10) diantaranya adalah kurangnya keterlibatan siswa dalam mempelajari matematika, kesulitan siswa dalam memahami materi matematika, dan ketergantungan siswa pada memori jangka pendek ketika mempelajari matematika. Dari beberapa penyebab tersebut, pembelajaran menggunakan pendekatan discovery berkontribusi dalam mengurangi kecemasan matematika. Pembelajaran discovery merupakan pembelajaran yang berorientasi pada siswa sehingga menekankan dalam keaktifan siswa. Menurut Arends (2012, p.402), dalam pembelajaran penemuan yang menekankan pada keaktifan, pengalaman belajar berpusat pada siswa dimana siswa menemukan ide-ide mereka dan memperoleh maknanya sendiri.

Selain itu, dalam tahapan pembelajaran discovery terdapat tahapan yang dapat mengurangi kecemasan matematika diantaranya tahap mengidentifikasi, mengumpulkan informasi, menganalisis, dan menyimpulkan. Pada tahap mengidentifikasi, siswa sudah dapat menentukan suatu masalah sehingga siswa sudah punya titik awal apa yang akan dipelajari, dengan demikian siswa tidak bingung dan sudah punya arah apa yang selanjutnya harus dilakukan. Pada tahap mengumpulkan informasi, bukan guru yang memberikan cara tertentu untuk digunakan siswa dalam menyelesaikan suatu masalah, tetapi siswa sendiri yang berusaha mencari untuk menemukan konsep yang dipelajari. Hal ini berdampak positif pada keaktifan siswa dalam membangun pengetahuannya sendiri.

Pada tahap menganalisis, siswa menyelesaikan soal-soal dengan mandiri. Pada tahap menyimpulkan, siswa dapat menyimpulkan konsep masalah yang dihadapi. Dari tahapan-tahapan tersebut, secara umum dapat dilihat bahwa siswa terlibat aktif dan pada akhirnya paham dengan konsep yang mereka pelajari. Karena siswa memperoleh pemahaman mereka sendiri, besar kemungkinan siswa tersebut tidak mengalami kesulitan belajar. Dapat dikatakan bahwa tahapan-tahapan dalam pembelajaran discovery dapat dijadikan alternatif untuk mengantisipasi kecemasan matematika yang disebabkan oleh kesulitan belajar siswa.

Selain itu, pada pembelajaran discovery, soal-soal yang diberikan bukan semata-mata soal pure mathematic, tetapi juga soal-soal kontekstual. Dengan demikian, siswa dapat mengaitkan konsep yang diperoleh dengan kehidupan seharihari agar pembelajaran yang dilalui oleh siswa menjadi lebih bermakna dan terus diingat. Disinilah peran pembelajaran discovery dalam mengurangi kecemasan matematika yang disebabkan ketergantungan terhadap memori jangka pendek.

\section{Hasil Uji Hipotesis}

Hasil uji normalitas multivariat dan univariat, uji homogenitas matriks varians kovarian secara berturut-turut bisa dilihat pada Tabel 5, Tabel 6, dan Tabel 7.

Tabel 5. Hasil Uji Normalitas Multivariat

\begin{tabular}{lccc}
\hline \multicolumn{1}{c}{ Kelas } & $d_{i}^{2}$ Pretest & $d_{i}^{2}$ Posttest & Ket \\
\hline CTL & 46,88 & 46,88 & normal \\
Discovery & 56,25 & 46,88 & normal \\
\hline
\end{tabular}

Tabel 5 menunjukkan bahwa sekitar $50 \%$ data memiliki nilai $d_{i}^{2}<\chi^{2}{ }_{(3 ; 0,5)}$. Dapat disimpulkan bahwa asumsi normalitas untuk kedua kelas terpenuhi.

Tabel 6. Hasil Uji Normalitas Univariat

\begin{tabular}{clc}
\hline Kelompok & \multicolumn{1}{c}{ Variabel } & Sig. \\
\hline \multirow{3}{*}{ CTL } & Prestasi belajar & 0,676 \\
& Kemampuan berpikir kritis & 0,611 \\
& Kecemasan matematika & 0,795 \\
\hline \multirow{3}{*}{ Discovery } & Prestasi belajar & 0,155 \\
& Kemampuan berpikir kritis & 0,257 \\
& Kecemasan matematika & 0,054 \\
\hline
\end{tabular}

Berdasarkan Tabel 6, diketahui bahwa nilai signifikansi yang diperoleh untuk keseluruhan data tersebut lebih dari 0,05. Dengan demikian asumsi normalitas terpenuhi untuk semua kelas baik sebelum dan sesudah perlakuan.

Tabel 7. Hasil Uji Homogenitas

\begin{tabular}{cccc}
\hline Nilai & $\begin{array}{c}\text { Sebelum } \\
\text { perlakuan }\end{array}$ & $\begin{array}{c}\text { Setelah } \\
\text { perlakuan }\end{array}$ & Keterangan \\
\hline Sig. & 0,122 & 0,278 & Homogen \\
\hline
\end{tabular}

Berdasarkan Tabel 7, terlihat bahwa nilai signifikansi lebih dari $\alpha=0,05$. Dapat disimpul- 
Pythagoras, 13 (2), 2018 - 177

Enggar Prasetyawan

kan bahwa matriks varians kovarians kedua kelompok eksperimen sebelum dan setelah diberi perlakuan pendekatan CTL dan pendekatan discovery adalah homogen.

\section{Uji Keefektifan Pendekatan Pembelajaran}

Perhitungan one sample t-test menggunakan taraf signifikansi 0,05 . Pengujian dilakukan dengan bantuan SPSS 17.0 for windows. Adapun hasil uji one sample t-test disajikan pada Tabel 8.

Tabel 8. Hasil Uji Keefektifan Pendekatan Pembelajaran

\begin{tabular}{clcc}
\hline Kelompok & \multicolumn{1}{c}{ Variabel } & $\mathrm{t}$ & Sig. \\
\hline \multirow{5}{*}{ CTL } & Prestasi belajar & 2,243 & 0,016 \\
& $\begin{array}{l}\text { Kemampuan berpikir } \\
\text { kritis }\end{array}$ & 1,805 & 0,041 \\
& $\begin{array}{l}\text { Kecemasan } \\
\text { matematika }\end{array}$ & $-1,749$ & 0,045 \\
\hline \multirow{5}{*}{ Discovery } & $\begin{array}{l}\text { Prestasi belajar } \\
\text { Kemampuan berpikir }\end{array}$ & 1,733 & 0,047 \\
& $\begin{array}{l}\text { Kecemasan } \\
\text { matematika }\end{array}$ & 1,805 & 0,041 \\
\hline
\end{tabular}

Berdasarkan Tabel 8, terlihat bahwa nilai signifikansi dari data posttest prestasi belajar, kemampuan berpikir kritis dan kecemasan matematika siswa setelah diberi perlakuan pendekatan CTL kurnag dari $\alpha=0,05$. Dapat disimpulkan bahwa pendekatan CTL efektif ditinjau dari prestasi belajar, kemampuan berpikir kritis dan kecemasan matematika siswa.

Nilai signifikansi data posttest prestasi belajar, kemampuan berpikir kritis dan kecemasan siswa setelah diberi perlakuan pendekatan discovery kurang dari $\alpha=0,05$. Dapat disimpulkan bahwa pendekatan discovery efektif ditinjau dari prestasi belajar, kemampuan berpikir kritis dan kecemasan matematika siswa.

\section{Uji Perbedaan Keefektifan Pendekatan Pembelajaran}

Setelah asumsi normalitas dan homogenitas terpenuhi serta telah terbukti bahwa perlakuan menggunakan kedua pendekatan pembelajaran efektif ditinjau dari setiap variabel terikat, maka dapat dilakukan uji two-group MANOVA terhadap data posttest prestasi belajar, kemampuan berpikir kritis, dan kecemasan matematika kedua kelompok eksperimen untuk mengetahui adakah perbedaan keefektifan kedua pendekatan pembelajaran tersebut. Pengujian dilakukan dengan bantuan program SPSS 17.0 for windows. Hasil uji perbedaan keefektifan pendekatan CTL dan pendekatan Discovery dapat dilihat pada Tabel 9.
Tabel 9. Hasil Uji Perbedaan Keefektifan Pendekatan Pembelajaran

\begin{tabular}{cccc}
\hline Effect & Value & F & Sig. \\
\hline Hotelling's Trace & 0,022 & $0,449^{\mathrm{a}}$ & 0,719 \\
\hline
\end{tabular}

Berdasarkan Tabel 9, menunjukkan bahwa nilai signifikansi yang diperoleh lebih dari $\alpha=$ 0,05 . Dapat disimpulkan bahwa tidak terdapat perbedaan keefektifan antara pendekatan CTL dan pendekatan discovery ditinjau dari prestasi belajar, kemampuan berpikir kritis dan kecemasan matematika siswa, sehingga tidak perlu dilakukan uji lanjut.

Adapun faktor yang diperkirakan menjadi penyebab tidak adanya perbedaan keefektifan antara kedua kelas eksperimen adalah kedua pendekatan pembelajaran sama-sama mengedepankan keterlibatan siswa dalam pembelajaran. Dalam kedua pembelajaran tersebut siswa dituntut untuk aktif dalam belajar agar mereka dapat menemukan konsep belajar secara mandiri.

Ditinjau dari kegiatan pembelajarannya, tahapan-tahapan pembelajaran pada kedua pendekatan memiliki karakteristik yang tidak jauh berbeda. Misalnya pada kegiatan memperoleh konsep pembelajaran melalui jalan menemukan, yakni pada pembelajaran dengan pendekatan CTL siswa menemukan konsep matematikanya melalui aktifitas experiencing. Pengetahuan yang diperoleh siswa melalui pembelajaran yang mengedepankan proses berpikir kritis lewat siklus menemukan. Dalam pendekatan discovery terdapat aktifitas mengumpulkan informasi yakni siswa diberi kebebasan untuk mengumpulkan berbagai informasi dari sumber belajar apapun misalnya buku, LKS, internet, bertanya kepada guru (narasumber) untuk menemukan konsep belajarnya, dengan pengamatan atau pengawasan guru.

Selain itu dalam pembelajaran CTL, siswa ditengah-tengah pembelajaran melakukan aktivitas presentasi hasil diskusi kelompok atau mengkomunikasikan. Dalam kesempatan ini, siswa dari anggota kelompok lain diberikan kesempatan untuk memberikan tanggapan atas informasi yang disampaikan kelompok lain. Pada pendekatan CTL anggota kelompok terdiri dari empat siswa. Aktivitas senada juga terdapat dalam pembelajaran dengan menggunakan pendekatan discovery, hanya saja yang membedakan dalam satu kelompok terdiri dari dua siswa atau teman sebangkunya. Berdasarkan hasil penelitian dan hal-hal yang diuraikan di atas, maka peneliti menyimpulkan tidak terdapatnya perbedaan keefektifan antara pendekatan CTL dan pendekatan 
discovery besar kemungkinan disebabkan oleh faktor karakteristik kedua pendekatan pembelajaran yang tidak jauh berbeda.

\section{SIMPULAN}

Berdasarkan hasil analisis data dan pembahasan, dapat disimpulkan beberapa hal sebagai berikut: (1) Pendekatan Contextual Teaching and Learning (CTL) efektif ditinjau dari prestasi belajar, kemampuan berpikir kritis, dan kecemasan matematika; (2) Pendekatan discovery efektif ditinjau dari prestasi belajar, kemampuan berpikir kritis, dan kecemasan matematika; (3) Tidak terdapat perbedaan keefektifan antara pendekatan Contextual Teaching and Learning (CTL) dan pendekatan discovery ditinjau dari prestasi belajar, kemampuan berpikir kritis, dan kecemasan matematika.

Terkait dengan hasil dan temuan yang diperoleh dalam penelitian ini serta keterbatasan penelitian yang ada, disarankan bagi guru untuk (1) menerapkan kedua pendekatan pembelajaran tersebut dalam pembelajaran matematika sehingga membawa dampak positif pada peningkatan prestasi belajar dan kemampuan berpikir kritis siswa, serta dapat mengurangi kecemasan matematika pada siswa; (2) dapat terus menggali serta mengkaji faktor-faktor kemungkinan lainnya yang mempengaruhi keefektifan pendekatan pembelajaran Contextual Teaching and Learning (CTL) dan pendekatan discovery sehingga pembelajaran dapat menjadi lebih efektif..

\section{DAFTAR PUSTAKA}

Apriza, B. (2015). Keefektifan pendekatan pembelajaran problem-based learning (PBL) dan pendekatan discovery setting think pair share (tps) pada materi program linier ditinjau dari prestasi belajar, kemampuan berpikir kritis, dan kepercayaan diri siswa SMK. Tesis. Yogyakarta: Universitas Negeri Yogyakarta.

Arem, C. (2010). Conquering math anxiety. Belmont, CA: Brooks/Cole.

Arends, R. I. (2012). Learning to teach ( $\left.9^{\text {th }} e d\right)$. New York, NY: McGraw-Hill.

Ashcraft, M. H. (2002). Math anxiety: Personal, educational, and cognitive consequences. Current Directions in Psychological Science, 11, 181-185.

Baker, E. D., Hope, L. \& Karandjeff. K. (2009). Contextualized teaching and learning: a faculty primer. California, CA: Community colleges.

Blazer, C. (2011). Strategies for reducing math anxiety. Journal Information Capsule Research Services, Vol. 1102, 1-8.

Brink, R., V., \& Budgen. (2006). Critical thinking for A2. Oxford: Howtobooks

Castronova, J. A. (2002). Discovery learning for the $21^{\text {st }}$ century: What is it and how does it compare to traditional learning in effectiveness in the $21^{\text {st }}$ century? Retrived from

http://www.myenglishpages.com/files/128 2044031.pdf

Crawford, M. C. (2001). Teaching contextually research, rationale, and techniques for improving student motivation and achievement in mathematics and science. Waco, Texas, TX: CCI Publishing, Inc.

Cruickshank, D. R., Jenkins, D. B., \& Metcalf, K. K. (2012). The act of teaching $\left(6^{\text {th }} e d\right)$. New York, NY: McGraw-Hill.

Ennis, R. H. (1996). Critical thinking disposition: Their nature and assessability. Informal Logic, 18(2), 165-182.

Ennis, R. H. (2011). The nature of critical thinking: an outline of critical thinking dispositions and abilities. Presentation at the Sixth International Conference on Thinking at MIT, Cambridge, MA. Diambil tanggal 27 Agustus 2015, dari http://faculty.education.illinois.edu/rhenni s/documents/TheNatureofCriticalThinkin g_51711_000.pdf.

Gambrill, E., \& Gibbs, L. (2009). Critical thinking for helping professional. Madison Avenue, NY: OXFORD University Press.

Jacob, S. M. (2012). Mathematical achievement and critical thinking skills in asynchronous discussion forums, Social and Behavioral Sciences, 31 (2012), 800-804.

Johnson, E. B. (2002). Contextual teaching and learning: menjadikan kegiatan belajarmengajar mengasyikkan dan bermakna. California, CA: Corwin Press, Inc. Diterjemahkan dari Contextual Teaching and Learning: What it is and why it's here to stay. Thousand Oaks: Corwin Press,Inc.

Kamaei, A. \& Weisani, M. (2013). The relationship between achievement motivation, critical thinking and creative 
thinking with academic performance. Indian Journal of Fundamental and Applied Life Science, 3(4), 121-127.

Kemendikbud. (2014). Permendikbud nomor 59 tahun 2014 tentang Kurikulum SMA. Jakarta: Kementerian Pendidikan dan Kebudayaan.

Lau, J.Y.F. (2011). An introduction to critical thinking and creativity: Think more, think better. Hoboken, NJ: John Wiley \& Sons, Inc.

Muslich, M. (2008). KTSP pembelajaran berbasis kompetensi dan kontekstual. Jakarta, ID: Bumi Aksara.

Mayer, D.P. (2008). Overcoming school anxiety: how to help your child deal with separation, tests, homework, bullies, math pobia, and other worries. New York, NY: AMACOM

Napitupulu, E. E. (2008). Mengembangkan strategi dan kemampuan siswa memecahkan masalah matematik. PYTHAGORAS: Jurnal Pendidikan Matematika, 4(2), 26-36. https://journal.uny.ac.id/index.php/pythag oras/article/view/557

NCTM. (2000). Principles and standards for school mathematics. Reston, VA: Person Education

Nitko, A. J. \& Brookhart, S. M. (2011). Educational assesment of students. Upper Saddle River, NJ: Pearson-Merrill Pentice Hall.

OECD. (2004). Learning for tomorrow's world: first results from pisa 2003. Paris: OECD. Diambil tanggal 28 Desember 2015, dari http://www.oecd.org/ education/school/programmeforinternationals tudentassessmentpisa/34002216.pdf.

OECD. (2014). PISA 2012 results: What students know and can do-student performance in mathematics, reading and science (Volume I, Revised edition, February 2014). PISA. OECD Publishing.

Paul, R., \& Elder, L. (2008). The miniature guide to critical thinking concepts and tools. Announcing the $28^{\text {th }}$ annual international conference on critical thinking. Near University of California at Baerkeley.

Rahmawati E.S, Y., \& Harta, I. (2014). Keefektifan pendekatan open-ended dan CTL ditinjau dari hasil belajar kognitif dan afektif. Jurnal Riset Pendidikan Matematika, 1(1), 113-126. doi:http://dx.doi.org/10.21831/jrpm.v1i1 . 2669

Reynolds, C. R, Livingston, R. B., \& Wilson, V. (2010) Measurement and assesment in education ( $2^{\text {nd }}$ ed.). Upper Saddle River, NJ: Pearson Education, Inc.

Saab, N, Joolingen, W. R, \& Wolters, B. H. A. M. (2005). Communication in collaborative discovery learning. British Journal of Educational Psychology, 75(4), 603-621.

Schunk, D. H. (2012). Learning theories. (terjemahan Eva Hamdiah \& Rahmat Fajar). Upper Saddle River, NJ: Pearson Education Inc.

Septiana, A. (2015). Keefektifan pendekatan contextual teaching and learning (CTL) dan inkuiri ditinjau dari prestasi belajar, kemampuan pemecahan masalah, dan adversity quotient terhadap matematika siswa SMP Negeri 1 Curup Tengah kelas VII semester 2. Tesis. Universitas Negeri Yogyakarta.

Sherman, B.F. \& Wither, D.P. (2003). Mathematics anxiety and mathematics achievement. Mathematics Education Research Journal, 15(2), 138-150.

Siregar, N., \& Marsigit, M. (2015). Pengaruh pendekatan discovery yang menekankan aspek analogi terhadap prestasi belajar, kemampuan penalaran, kecerdasan emosional spiritual. Jurnal Riset Pendidikan Matematika, 2(2), 224234.doi:http://dx.doi.org/10.21831/jrpm.v $2 \mathrm{i} 2.7336$

Slavin, R. E. (2006). Educational pschology theory and practice eighth edition. Boston, MA: Pearson Education, Inc.

Smith, A. (2013). Can inquiry math resolve math anxiety?. Diambil tanggal 22 februari 2016 dari http://www.yrdsb.ca/ Programs/PLT/Quest/Journal/2013-Caninquiry-math-resolve-math-anxiety.pdf.

Smith, B. P. (2010). Instructional strategies in family and consumer sciences: Implementing the contextual teaching and learning pedagogical model. Journal of Family \& Consumer Sciences Education, 28(1), 23-38. 


\section{Pythagoras, 13 (2), 2018 - 180}

Enggar Prasetyawan

Sousa, D. A. (2008). How the brain learns mathematics. Thaousand Oaks, CA: Corwin Press.

Stevens, J. P. (2009). Applied multivariate statistics for the social sciences fifth edition. New York, NY: Taylor \& Francis Group.

Syahbana, A. (2012). Peningkatan kemampuan berpikir kritis matematis siswa SMP melalui pendekatan contextual teaching and learning. Edumatica, 02(01), 45-57.

Tatsuoka, M. M. (1971). Multivariate analysis: Techniques for educational and psychological research. New york, NY: John Wiley \& Sons, Inc.

Thijsse, L.J. (2002). The effects of a structured teaching method on mathematics anxiety and achievement of grade eight learners. Thesis Master of Education. University of South Africa.

Westwood, P. (2008). What teacher need to know about teaching methods. Victoria, AU: ACER Press.

Zakaria, E. \& Nordin, N. M. (2008). The effects of mathematics anxiety on matriculation students as related to motivation and achievement. Eurasia Journal of Mathematics, Science \& Technology Education, 2008, 4(1), 27-30

Zeidner, M. \& Matthews, G. (2011). Anxiety 101. New York, NY: Springer Publishing Company.. 